\title{
MODEL DISEMINASI PENERAPAN MOBILE MONEY DI MASYARAKAT PEDESAAN KABUPATEN TASIKMALAYA
}

\author{
DISSEMINATION MODEL OF MOBILE MONEY APPLICATION IN RURAL COMMUNITIES IN \\ TASIKMALAYA DISTRICT
}

\author{
Edi Sukmadirana $^{*}$, Kudang Boro Seminar ${ }^{* * *}$, Muhammad Firdaus ${ }^{* * *}$, dan Yandra Arkeman ${ }^{* *}$ \\ ${ }^{*}$ Sekolah Bisnis, IPB University \\ Jl. Raya Pajajaran, Bogor 16151 \\ **) Departemen Teknik Mesin dan Biosistem, Fakultas Teknologi Pertanian, IPB University \\ Jl. Lingkar Akademik, Kampus IPB Darmaga, Bogor, Jawa Barat 16680 \\ ***) Departemen Ilmu Ekonomi, Fakultas Ekonomi dan Manajemen, IPB University \\ Jl. Agatis, Kampus IPB Darmaga, Bogor, Jawa Barat 16680
}

\begin{abstract}
Tasikmalaya District is one of the West Java regions with good agribusiness potentials in food crops and ruminant livestock. The potentials must be utilized properly to have an impact on regional economic improvements. This research aimed to design a dissemination model for mobile money application in rural communities, especially in Tasikmalaya District, in three sub-districts: Singaparna, Rajapolah, and Ciawi, using a structured approach through Soft System Methodology (SSM). The model must be built in a system, through a four-layered model, with components for each layer: a) Layer-1 consists of values, infrastructure (network, smartphone, merchant), customer capabilities, $\&$ regulations; b) Layer-2 consists of institutional support (local government and related agencies); c) Feature, communities, and communication media; d) Sweetener program. In the implementation process, layer-1's readiness is a priority that must be met first, followed by layer-2, layer-3, and layer-4's readiness.
\end{abstract}

Keywords: dissemination model, soft system methodology, mobile money, Tasikmalaya

\begin{abstract}
Abstrak: Kabupaten Tasikmalaya merupakan salah satu wilayah di Jawa Barat yang memiliki potensi agribisnis pada komoditas tanaman pangan dan ternak ruminansia yang baik. Potensi agribisnis yang prospektif tersebut harus dimanfaatkan dengan baik agar dapat memberikan dampak peningkatan ekonomi bagi wilayah tersebut. Penelitian ini bertujuan untuk merancang bangun model diseminasi untuk penerapan mobile money di masyarakat pedesaan khususnya di Kabupaten Tasikmalaya di tiga kecamatan yaitu: Singaparna, Rajapolah dan Ciawi, dengan menggunakan pendekatan terstruktur melalui Soft System Methodology. Dalam merancang model diseminasi untuk penerapan mobile money di masyarakat pedesaan Kabupaten Tasikmalaya harus dibangun secara sistem, melalui model 4 layer, dengan komponen setiap layer adalah a) Layer 1 terdiri dari value, infrastrukutur (Jaringan, smartphone, merchant), kemampuan customer dan regulasi, b) Layer 2 terdiri dari dukungan kelembagaan (pemda dan instansi terkait) c) Layer 3 terdiri dari Feature, komunitas dan media komunikasi, d) Layer 4 terdiri dari Program sweetener. Dalam proses implementasinya kesiapan layer 1 merupakan skala prioritas yang harus dipenuhi terlebih dahulu, kemudian kesiapan layer 2, 3 dan 4.
\end{abstract}

Kata kunci: model diseminasi, soft system methodology, mobile money, Tasikmalaya

\footnotetext{
${ }^{1}$ Alamat Korespondensi:

Email: edisukma2016@gmail.com
} 


\section{PENDAHULUAN}

Modernisasi menuntut cara hidup serba cepat dan instan termasuk dalam kegiatan transaksi. Kehadiran teknologi mobile money sebagai salah satu yang dapat menjawab permasalahan tersebut. Penggunaan mobile money di Indonesia mendapat respon positif, khususnya dari masyarakat perkotaan. Menurut Bank Indonesia (2020) menunjukkan volume transaksi uang elektronik di Indonesia dari tahun 2012 hingga tahun 2019 mengalami peningkatan. Volume transaksi tersebut mengalami peningkatan tajam pada tahun 2018 hingga 2019 dimana volume transaksi mencapai 5,2 miliar transkasi dengan nilai nominal Rp145,2 Triliun meningkat tiga kali lipat dari tahun sebelumnya.

Penerapan mobile money perlu dikembangkan ke wilayah pedesaan secara bersama-sama antara perbankan, penyedia jasa mobile money, operator telekomunikasi dan Pemerintah Daerah (Pemda), karena sangat mendukung kegiatan agribisnis di Indonesia. Berdasarkan data Otoritas Jasa Keuangan (OJK) hanya $49 \%$ orang yang memiliki rekening perbankan di tahun 2019 dan banyak yang memiliki rekening lebih dari satu, sehingga diperkirakan hanya 50 juta penduduk yang dilayani oleh perbankan dari 267 juta jiwa penduduk Indonesia. Membangun ekosistem mobile money di masyarakat pedesaan sebagai solusi atas kendala keterbatasan dalam mengakses perbankan, karena sebagian masyarakat pedesaan tidak bisa memenuhi persyaratan administrasi yang harus di penuhi perbankan dan keterbatasan bank dalam pengembangan kantor cabang di pedesaan.

Kabupaten Tasikmalaya, khususnya Kecamatan Singaparna, Rajapolah dan Ciawi memiliki potensi agribisnis pada komoditas tanaman pangan dan ternak ruminansia yang baik. Potensi ini harus didukung dengan meningkatkan literasi mobile money agar dapat bertransaksi dengan pembeli yang lebih luas, cepat dan akuntabel. Model diseminasi penerapan mobile money untuk masyarakat pedesaan perlu dirancang untuk menunjang pengembangan Agribisnis. Permasalahan penerapan mobile money saat ini diantaranya: 1) perkembangan teknologi dan inovasi yang cepat, 2) tingkat kepercayaan transaksi non tunai masih rendah, 3) gap antara kecepatan perkembangan teknologi dan kompetensi masyarakat, serta 4) ekosistem belum terbentuk.
Berdasarkan uraian permasalahan yang telah dijelaskan sebelumnya, tujuan penelitian ini adalah merancang model diseminasi yang baik untuk penerapan mobile money di masyarakat pedesaan. Ruang lingkup penelitian : 1) Penelitian dilakukan di tiga kecamatan yaitu Kecamatan Singaparna, Kecamatan Rajapolah, dan Kecamatan Ciawi, 2) Teknologi mobile money application base, 3). Survei dilakukan terhadap lebih dari 200 responden. Terkait dengan kebaruan dalam penelitian ini diantaranya yaitu 1). Transformasi diseminasi dengan pemanfaatan teknologi informasi dan komunikasi (ICT), 2). Prototipe model diseminasi mobile money untuk masyarakat pedesaan, 3). Meminimalisasi GAP antara perkembangan teknologi dan kemampuan masyarkat pedesaan, 4). Memberikan pemahaman yang lebih baik dalam membangun model diseminasi yang harus diterapkan untuk masyarakat pedesaan.

\section{METODE PENELITIAN}

Penelitian dilakukan pada bulan September 2019 sampai Maret 2020 di tiga Kecamatan (Singaparna, Rajapolah, dan Ciawi) di Kabupaten Tasikmalaya, Provinsi Jawa Barat. Jenis dan sumber data penelitian adalah data primer dan sekunder. Data sekunder diperoleh dari studi literatur, Badan Pusat Statistik (BPS), provider mobile money, operator telekomunikasi, perbankan dan Bank Indonesia. Pengumpulan data primer melalui survei dan wawancara yang mendalam kepada 207 orang masyarakat pedesaan yang berdomisili di tiga kecamatan dan pernah menggunakan mobile money. Responden terdiri dari 41 orang pelajar dan mahasiswa, 45 orang PNS/TNI/Polri/Pegawai Swasta, 50 orang Pedagang/Wiraswasta serta 71 orang Buruh/Petani.

Penelitian ini menggunakan pendekatan analisis Soft System Methodology (SSM), melalui 7 tahapan proses diantaranya yaitu: 1) Situation Considered Problematic, 2) Problem Situation Expressed, 3) Root Definitions of Relevant Systems, 4) Conceptual Models, 5) Comparisons with Reality, 6) Debate about change dan tahapan terakhir yaitu 7) Action (tindakan), yaitu melakukan tindakan perbaikan awal dalam memperbaiki keadaan. Hipotesis yang dibangun dalam penelitian ini adalah sebagai berikut:

H1 = Persepsi kemudahan merupakan faktor pertama yang harus terpenuhi

$\mathrm{H} 2=$ Persepsi manfaat merupakan kritikal faktor kedua yang harus di penuhi 
$\mathrm{H} 3=$ Behavioural Intention merupakan kritikal faktor ketiga yang harus dipenuhi

$\mathrm{H} 4=$ Usage behaviour merupakan kritikal faktor keempat yang harus dipenuhi

\section{HASIL}

\section{Situasi Kondisi Saat ini}

Hasil pertanian yang cukup melimpah menjadi latar belakang pentingnya diseminasi mobile money untuk menunjang pengembangan hasil pertanian masyarakat pedesaan. Kabupaten Tasikmalaya yang memiliki 38 Kecamatan menjadi daerah penerima bantuan paling tinggi yaitu sebesar 744 miliar rupiah (Kompas, 2019). Sementara kondisi sosial dan ekonomi di Kecamatan Rajapolah, Ciawi, dan Singaparna saat ini dijelaskan pada Tabel 2. Kondisi penggunaan mobile money, penyuluh pertanian dan sarana telekomunikasi, infrastruktur, di Kabupaten Tasikmalaya dijelaskan pada Tabel 3.

\section{Rich Picture}

Rich picture yang menggambarkan kondisi infrastruktur dan komponen-komponen yang terkait dengan mobile money yang ada di tiga kecamatan (Singaparna, Ciawi dan Rajapolah) saat ini seperti pada Gambar 1.

\section{Root Definition (RD)}

Root definition merupakan pernyataan aktivitas yang terjadi atau mungkin terjadi di tengah-tengah masyarakat Kabupaten Tasikmalaya. Rumusan Root Definition sebagai berikut: 1) (X) Model diseminasi mobile money dari tradisional ke digitalisasi dengan penerapan ICT yang sesuai dengan kemampuan dan kebutuhan masyarakat pedesaan, media yang digunakan, konten yang diberikan dan frekuensi penyampaian, 2) (Y): Penerapan ICT untuk model diseminasi mobile money harus dilakukan secara sistematis dan masif baik teori maupun praktik dengan didukung sarana dan prasana yang memadai, 3) (Z): Penerapan ICT dalam model diseminasi untuk masyarakat pedesaan akan lebih efektif, efisien, standarisasi konten, kualitas penyampaian, serta menjawab kecepatan perubahan informasi dan kekuarangan tenaga penyuluh di pedesaan. Terkait dengan hasil analisis CATWOE (Customer, Actor, Transformation, World view, Owner, Environment constraint) dipetakan secara rinci pada Tabel 4.

Tabel 1. Transaksi non-tunai di Indonesia tahun 2012-2019

\begin{tabular}{lcccccccc}
\hline Periode & 2012 & 2013 & 2014 & 2015 & 2016 & 2017 & 2018 & 2019 \\
\hline Nominal (Rp triliun) & 2,0 & 2,9 & 3,3 & 5,3 & 7,1 & 12,4 & 47,2 & 145,2 \\
Volume (juta) & 101 & 138 & 203 & 536 & 683 & 943 & 2923 & 5227 \\
\hline
\end{tabular}

Sumber: Bank Indonesia (2020)

Tabel 2. Kondisi sosial ekonomi di Kecamatan Rajapolah, Ciawi, dan Singaparna

\begin{tabular}{llll}
\hline Kondisi Saat Ini & Kecamatan Rajapolah & Kecamatan Ciawi & Kecamatan Singaparna \\
\hline Kondisi & Jumlah Lembaga keuangan di & Jumlah Lembaga keuangan di & Jumlah Lembaga keuangan di \\
Perekonomian & tahun 2018 ada 8 Bank & tahun 2018 ada 16 Bank & tahun 2018 ad 21 Bank \\
(BPS, 2019) & Jumlah Koperasi : KUD 10, & Jumlah Koperasi Aktif berjumlah & Jumlah Koperasi Aktif : KUD \\
& koperasi simpan pinjam 5. & 10 & dua dan Koperasi Simpan \\
& Jumlah toko kelontong 581, & Jumlah toko kelontong 672, Pasar & Pinjam delapan \\
& mini market 7 dan pasar & umum 1 dan pasar hewan 1 & Jumlah Pertokoan besar \\
& permanen 2 & Warung makan 116 & sebanyak 12, Pasar permanen \\
& Jumlah restoran 12 dan & Industri Kerajinan Kayu 23, & 2, pasar semi permanen 3, \\
& warung makan 49 & Anyaman 48, Keramik 13 dan & mini market 20 \\
& Industri Kerajinan : Anyaman & Makanan 321 & Jumlah Restoran 25, \\
& 1824, Kulit 233, Kayu lima & Jasa alat pesta 39, photocopy 21, & warung makan 320, hotel 1, \\
& belas, Logam Mulia tiga belas, & salon 53, photo studio 3, warnet 33, Penginapan 1 dan Warung \\
& Kain 27, Bata Merah tujuh & reparasi elektronik 37 dan bengkel & Kelontong 939 \\
& dan makanan 32 & 52 & \\
\hline
\end{tabular}


Tabel 3. Kondisi penerapan mobile money di Kabupaten Tasikmalaya

\begin{tabular}{|c|c|}
\hline Indikator & Kondisi Saat Ini \\
\hline \multicolumn{2}{|c|}{ Kondisi Penerapan Mobile Money } \\
\hline $\begin{array}{l}\text { Produk Mobile } \\
\text { Money }\end{array}$ & $\begin{array}{l}\text { Produk mobile money yang lebih dikenal di masyarakat Kabupaten Tasikmalaya adalah Gopay, } \\
\text { OVO, dan Dana. } \\
\text { Mobile money yang ada selain Gopay, OVO dan Dana adalah Paytrend dan Al-Faqih Mobile } \\
\text { Payment yang beroperasi di lingkungan pesantren Pondok Pesantren Miftahul Huda Al-Faqih } \\
\text { yang berlokasi di Manonjaya. }\end{array}$ \\
\hline Value & $\begin{array}{l}\text { Value Gopay dan OVO yang bisa dimanfaatkan oleh masyarakat di tiga kecamatan adalah } \\
\text { transportasi online dan transaksi makanan dan minuman, sedangkan untuk produk yang lainnya } \\
\text { masih jarang peminatnya. } \\
\text { Value yang terdapat pada feature Gopay dan OVO belum di manfaatkan maksimal ole masyarakat } \\
\text { karena tidak ada sosialisasi yang sitematis dari pihak penyelenggara jasa dan masyarakat banyak } \\
\text { yang autodidak dalam mempelajari feature yang tersedia. }\end{array}$ \\
\hline Harga & $\begin{array}{l}\text { Keluhan perubahan harga Rp4.000/2km menjadi Rp9.000/4km. } \\
\text { Masyarakat di } 3 \text { kecamatan dan driver tak setuju dengan kenaikan tarif karena tidak menarik bagi } \\
\text { Masyarakat terutama jika jarak yang ditujunya rata-rata jarak dekat. } \\
\text { Top Up atau isi ulang melalui perbankan masih menjadi kendala bagi masyarkat karena } \\
\text { kebanyakan tidak menguasai internet banking. } \\
\text { Top up kebanyakan dilakukan melalui jasa driver ojol }\end{array}$ \\
\hline Discount & $\begin{array}{l}\text { Discount menjadi salah satu daya tarik bagi masyarakat untuk menggunakan Mobile Money. } \\
\text { Disisi lain ada sebagian masyarakat yang menganggap riba jika terjadi perbedaan harga antara } \\
\text { pembayaran cash dan pakai mobile money. }\end{array}$ \\
\hline Kemudahan & $\begin{array}{l}\text { Top up melalui driver Ojol banyak dilakukan oleh pengguna karena banyak yang belum memiliki } \\
\text { rekening di bank dan terkendala jarak lokasi mesin ATM. }\end{array}$ \\
\hline Penyampaian Produk & $\begin{array}{l}\text { Penyuluh pertanian (tunjangan Rp400.000 sedang diusulkan naik menjadi Rp1.500.000). } \\
\text { September } 2019 \text { dibentuk DCOS (Driver Community Ojol Singaparna). } \\
\text { Sosialisasi ke warga dilakukakan oleh DCOS di carefree day } \\
\text { Driver Community lainnya : Hardline, GSBC, Gaproek, Cigor, BR. }\end{array}$ \\
\hline \multicolumn{2}{|c|}{ Kondisi Penyuluh Pertanian } \\
\hline Tenaga Penyuluhan & $\begin{array}{l}\text { Kurangnya tenaga penyuluh di Kab Tasikmalaya, satu tenaga penyuluh untuk } 2-3 \text { desa dengan } \\
\text { jumlah kecamatan sebanyak } 39 \text { dan } 351 \text { desa dengan total tenaga penyuluh pertanian } 140 \text { orang, } \\
\text { hanya } 30 \% \text { dari PNS. } \\
\text { Pos Penyuluhan Desa (POSLUHDES) merupakan organisasi yang tumbuh dari inisiatif } \\
\text { masyarakat tani khususnya yang berada di desa/kelurahan sebagai sarana penyuluhan dan } \\
\text { pelayanan kepada masyarakat tani. }\end{array}$ \\
\hline Model Penyuluhan & $\begin{array}{l}\text { Model penyuluhan yang diterapkan kebanyakan Top Down. } \\
\text { Prakarsa Pemerintah. } \\
\text { Jenis produk yg dikomunikasikan produk pertanian. }\end{array}$ \\
\hline \multicolumn{2}{|c|}{ Regulasi dan Sarana Telekomunikasi } \\
\hline Regulasi & $\begin{array}{l}\text { Peraturan Bank Indonesia No 20/6/PBI/2018 tentang Uang Elektronik. } \\
\text { Mayoritas masyarakat tidak mengenal PBI tentang Uang Elektronik }\end{array}$ \\
\hline $\begin{array}{l}\text { Operator } \\
\text { Telekomunikasi }\end{array}$ & $\begin{array}{l}\text { Operator telekomunikasi yang telah beroperasi di Kabupaten Tasikmalaya adalah Telkomsel, } \\
\text { Indosat, XLAxiata, Hutch 3, Smartfren dengan kualitas layanan 3G/4G dan di area tertentu sinyal } \\
\text { kurang baik. }\end{array}$ \\
\hline
\end{tabular}


1

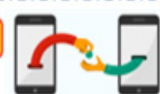

1.a Mobile money yang cukup dikenal di masyarakat kec Singaparna, Ciawai dan Rajapolah : Gopay, Ovo dan Dana.

1.b Feature layanan yang sering dipakai dan dikenal masyarakat adalah Ojol, GoFood

1.c Feature Layanan terus bertambah

1.d Perubahan Produk knowledge cepat

1.e Edukasi ke pelanggan belum terstruktur \& belum optimal

1.f Keluhan perubahan harga $\mathrm{Rp}$. $4 \mathrm{rb} / 2 \mathrm{~km}$ menjadi $9 \mathrm{rb} / 4 \mathrm{~km}$

1.g Mayoritas Top up dilakukan melalui driver ojol

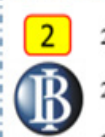

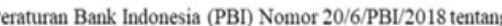
Uang Elektronik yang berlaku sejak 4 Mei 2018

$2 . b$ Kebijakan Mobile Money belum tersosialisasi dengan baik ke masyarakat

2.c Mayoritas masyarakat tidak mengenal PBI

2.d Koordinasi BI dengan lembaga terkait belum optimal

3.a Tiga operator besar telah beroperasi

(Tsel, ISAT dan Excel)

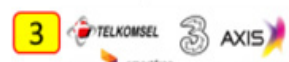

3.b Kualitas Jaringan $3 \mathrm{G} / 4 \mathrm{G}$ masil

terbatas di area Kabupaten

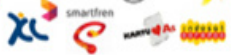

3.c Sinyal jaringan tidak konsisten kuat

4

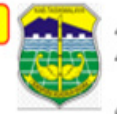

4.a, Dukungan sosialisasi dari Pemda Kurang

4.b. Saat ini tidak berdampak langsung terhadap benefit Pemda

4.c Bantuan keuangan tahun 2020744 miliar untuk Kabupaten Tasikmalaya

4.d Penyaluran dana bantuan untuk masyarakat melalui ATM BRI dan ATM Mandiri

5.a Jumlah merchant sangat terbatas

5.b Potensi penambahan merchant cukup besar UKM

kerajinan, kulit, warung kelonton

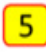

6

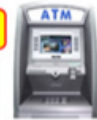

6.1 Jumlah ATM sangat terbatas

6.2 Mayoritas masyarakat belum terbiasa

menggunakan ATM

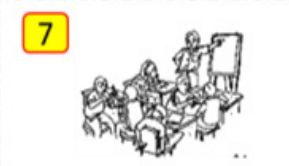

7.a Komunitas pengguna mobile money non driver belum terbentuk

7.b Komunitas driver mobile money belum optimal

7.c Iklan mobile money melalui

TV \& Koran sangat kurang

7.d Brosur belum menjangkau

masyarakat luas

7.e Komunitas Kelompok

merchant UKM Gopay dan

OVO belum terbentuk

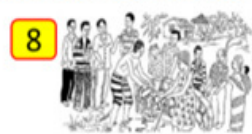

8.a Mobile Money belum memasyarakat

8.b Tidak ada pelatihan khusus cara penggunaan Medsos untuk masyarakat

8.c Masyarakat belajar autodidak

8.d. Masyarakat banyak yang tidak mengetahui perkembangan feature layanan

9

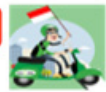

9. Kurang update informasi

9.b Informasi didapat dari teman

9.c Update produk dari Provider Ojol sangat jarang

9.d Hasil transaksi mobile mone selalu diambil tunai via ATM

9.e Profesi Ojol hanya sebagai

sampingan bagi sebagian

Driver sehingga kurang fokus

Gambar 1. Diagram rich picture penerapan mobile money di Kabupaten Tasikmalaya

Tabel 4. Analisis CATWOE

Komponen Root Hasil Definisi

Definition

C - Customers Masyarakat pengguna mobile money di Kecamatan Singaparna, Ciawi, dan Rajapolah Kabupaten

(Pelanggan) Tasikmalaya.

A - Actors Provider mobile money, Bank Indonesia, Perbankan, Pemerintah Daerah, Provider Telekomunikasi,

(Aktor)

$\mathrm{T}$ Merchant/ Pedagang.

Mengubah perilaku masyarakat pedesaan dalam penerapan ICT sebagai media komunikasi dan

Transformation informasi melalui media sosial whatsapp dan Youtube

Process (Proses

Transformasi)

W - Worldview

Perubahan perilaku masyarakat pedesaan dalam bertransaksi dengan menggunakan mobile money.

(Sudut Pandang)

O - Owners

Perubahan perilaku masyarakat dalam menerima informasi melalui ICT dan perubahan perilaku

(Pemilik Isu)

E - Environmental Ketersediaan infrastruktur : smartphone yang murah, jaringan 3G/4G, paket Data yang murah, jumlah constraints merchant dan listrik

(Hambatan

Lingkungan)

dalam bertransaksi dengan nontunai akan mempercepat terwujudnya cashless society.

Provider mobile money, Pemerintah dan Bank Indonesia

Kesadaran masyarakat untuk menggunakan mobile payment dan dukungan kebijakan dan program dari pemerintah untuk menggunakan mobile money dalam transaksi pembayaran yang dibawah kendali pemerintah daerah dan provider mobile money melalui pemberian diskon

Kemudahan dan manfaat yag dirasakan langsung oleh masyarakat pedesaan khususnya untuk mendukung usaha pertanian dengan program pembelian pupuk, bibit, alat pertanian yang lebih murah jika menggunakan mobile money 
Hasil penelitian yang dilakukan oleh Sukmadirana et al. (2020) dengan menggunakan metode SEM menyimpulkan bahwa indikator yang berkorelasi kuat terhadap pemahaman, kesadaran, dan aksi pada masyarakat pedesaan dalam menggunakan mobile money, adalah 1) value product mobile money yang ditawarkan harus sesuai dengan kebutuhan dan keinginan masyarakat, 2) kesiapan infrastruktur untuk mendukung terbentuknya ekosistem, 3) kemampuan masyarakat dari aspek pengetahuan maupun kemampuan finansial untuk mendapatkan gadget dan paket data, 4) penerapan media sosial sebagai media komunikasi dalam penyampaian program dan produk mobile money. Berdasarkan uraian sebelumnya maka didapatkan suatu root definition yang digambarkan terkait model desiminasi penerapan mobile money pada masyarakat pedesaan untuk menunjang pengembangan agribisnis. Secara rinci dapat dilihat pada Gambar 2 .

\section{Model Konseptual}

Gambaran model konseptual dalam mengidentifikasi aktivitas yang diperlukan dalam sistem diseminasi mobile money yang dibangun seperti pada Tabel 5 .

\section{Comparisons with Reality serta melakukan perubahan yang mungkin dilakukan (6) dan aksi untuk perbaikan situasi (7).}

Berdasarkan hasil perbandingan antara model konseptual dengan realitas, disusun suatu perubahan- perubahan yang dapat dilakukan untuk memperbaiki situasi yang ada. Hal-hal tersebut digambarkan pada Tabel 6. Dalam merancang model diseminasi yang terbaik untuk penerapan mobile money di masyarakat pedesaan Kabupaten Tasikmalaya harus dibangun secara sistem, melalui 4 layer dengan gambar model diseminasi seperti pada Gambar 3.

Layer 1: Membangun persepsi kemudahaan dengan memberikan kesempatan untuk mendapatkan pengalaman menggunakan mobile money bagi masyarakat, dengan cara : a) memiliki nilai tambah yang lebih baik dan sesuai dengan kebutuhan masyarakat pedesaan; b) pengenalan regulasi mobile money kepada masyarakat sebagi alat transaksi yang legal, aman dan bermanfaat bagi masyarakat; c) Perluasan merchant dengan merangkul KUD, UKM, petani, peternak, perkebunan, hortikultura dan perikanan, toko, mini market, kerajinan dan industri makanan; d) ketersediaan jaringan $3 \mathrm{G} / 4 \mathrm{G}$, kemudahan mendapatkan smartphone dan paket data yang murah melalui program bundling serta; e) pengenalan dan update informasi dalam bentuk video melalui media sosial. Hipotesis 1 (H1) terbukti bahwa persepsi kemudahan dalam mengakses dan menggunakan mobile money merupakan faktor utama yang harus terpenuhi. Hal ini sejalan dengan penelitian yang dilakukan oleh Barakabitze et al. (2015) yang menyimpulkan bahwa ketersedian jaringan listrik dan jaringan internet tujuh hari dalam seminggu dan 24 jam dalam sehari sebagai faktor penentu dalam keberhasilan penerapan ICT untuk masyarakat pedesaan.

\section{SUMBER}

AKTIFITAS

MEDIA

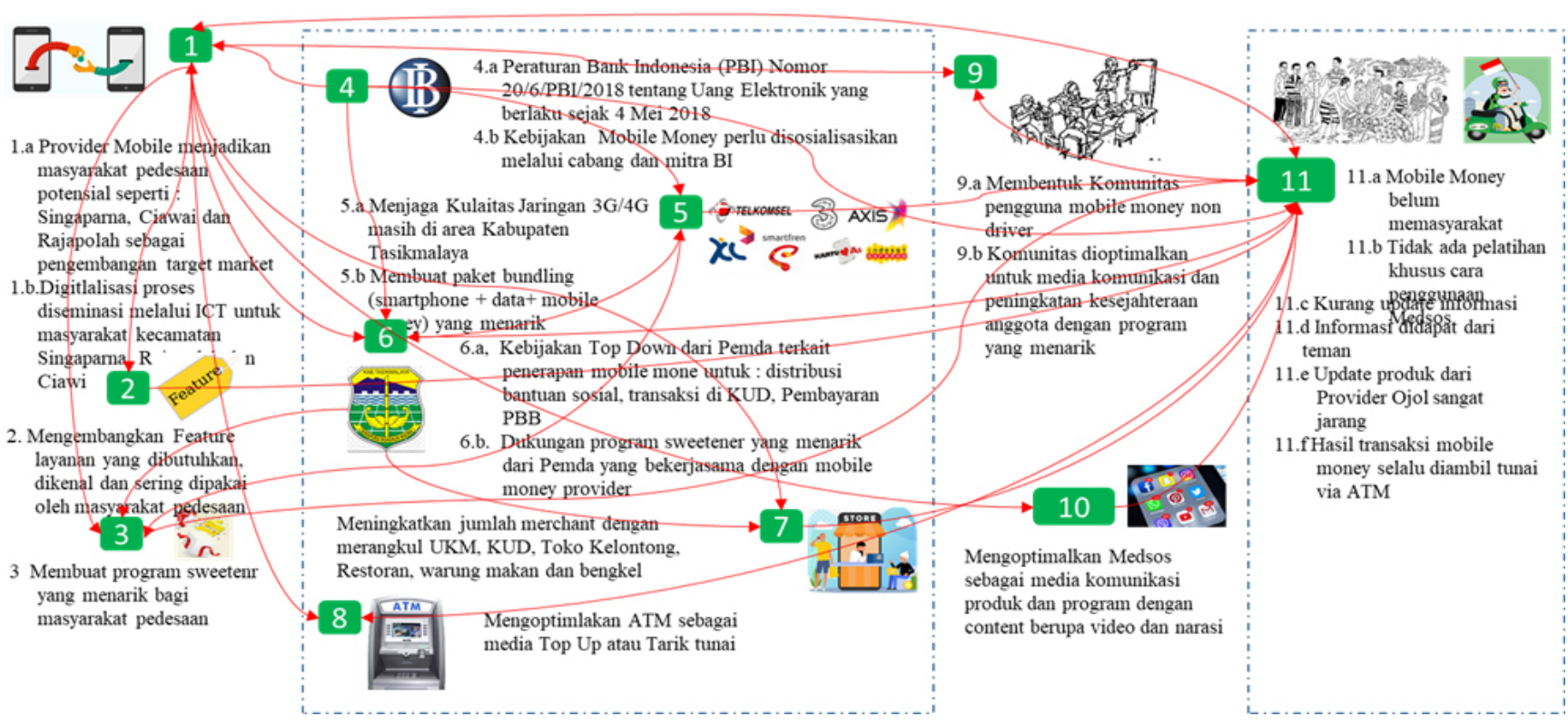

Gambar 2. Root definition 
Tabel 5. Model konseptual penelitian

\begin{tabular}{l}
\hline Model Konseptual \\
\hline SUMBER \\
Membuat Value Mobile Money yang \\
sesuai dengan kebutuhan masyarakat \\
pedesaan \\
Kepedulian provider untuk menjadikan \\
masyarakat pedesaan sebagai target \\
pasar
\end{tabular}

Referensi

Value merupakan Komponen yang berkorelasi kuat terhadap pemahaman, kesadaran dan aksi dengan Koefisien Standardized Loading Factor (SLF) 0,97. (Sukmadirana et al. 2020)

Penggunaan mobile money mampu meningkatkan masyarakat untuk menabung, meminjam, menerima dan pengiriman uang (Munyegera dan Matsumoto, 2015)

Hasil penelitian nilai koefisien SLF untuk provider 0,87 (Sukmadirana et al. 2020)

Digitalisasi proses diseminasi melalui ICT merupakan alat terkuat untuk mentransfer pengetahuan dan teknologi penerapan ICT untuk masyarakat pertanian kepada petani (Ankur dan Bidisha, 2013). ICT terbukti sebagai media Kecamatan Singaparna, Rajapolah, dan diseminasi efektif bagi Petani (Windi, 2014) Ciawi

Hasil penelitian nilai koefisien SLF untuk medsos 0,96 (Sukmadirana et al. 2020)

Mengembangkan feature layanan yang dibutuhkan, mudah dan sering dipakai oleh masyarakat pedesaan

Mengukur perubahan pengetahuan pada individu, melalui tiga dimensi yaitu : pemahaman (Zahra et al. 2000), kegunaan (Simonin, 1999; 2004) dan kecepatan (Zahra et al. 2000; Zander dan Kogut, 1995)

Hasil penelitian nilai koefisien SLF untuk keinginan 0,95 (Sukmadirana et al. 2020)

Membuat program sweetener yang menarik bagi masyarakat pedesaan

Hubungan baik antara sumber dan penerima mempercepat transfer knowledge (Nonaka 1996; Szulanski 1996)

Hasil penelitian nilai koefisien SLF diskon produk 0,88 dan harga produk 0,79 (Sukmadirana et al. 2020)

\section{AKTIVITAS}

Peraturan Bank Indonesia (PBI) Nomor 20/6/PBI/2018 tentang Uang Elektronik perlu disosialisasikan melalui cabang dan mitra BI

Kepedulian Pemda melalui kebijakan top down untuk penggunaan mobile money dalam bertransaksi harian masyarakat pedesaam

Proses digitalisasi perlu didukung dengan penyediaan program smartphone dan paket data yang murah

Peran pemerintah (Yongjian et al. 2015) dan pengaturan kelembagaan (Bollinger et al. 1994; Limbu 1999)

Memastikan keamanan dan efisiensi (Hoenig, 1995)

Hasil penelitian nilai koefisien SLF regulasi 0,87 (Sukmadirana et al. 2020)

Peran pemerintah (Yongjian et al. 2015) dan pengaturan kelembagaan

(Bollinger et al. 1994; Limbu, 1999).

Hasil penelitian nilai koefisien SLF politik 0,88. (Edi et al. 2020)

Permasalahan diseminasi adalah penyebaran informasi, pelatihan dan kesesuian teknologi (Limbu 1999)

Hasil penelitian nilai koefisien SLF infrastruktur 0,89 (Edi et al. 2020).

\section{MEDIA}

Informasi yang disampaikan dalam bentuk video, sering dan terdokumentasi akan mudah dipahami oleh masyarakat

Strategi difusi berbasis video dapat meningkatkan tingkat adopsi praktik pertanian hingga enam kali lipat (Ghandi et al. 2007), sejalan dengan temuan Gian dan Robert (2015), bahwa video dapat mendukung petani untuk menerapkan praktik inovasi

Penyampaian informasi melalui formal dan non formal (Ying dan Gina, 2019)

Hasil penelitian nilai koefisien SLF penyampaian produk 0,79 (Edi et al. 2020) 
Tabel 5. Model konseptual penelitian (lanjutan)

\begin{tabular}{|c|c|}
\hline Model Konseptual & Referensi \\
\hline \multirow[t]{2}{*}{$\begin{array}{l}\text { Penyampaian informasi melalui media } \\
\text { sosial }\end{array}$} & $\begin{array}{l}\text { Transfer pengetahuan akan efektif secara personal melalui jaringan sosial media } \\
\text { (Wang dan Ma, 2007) }\end{array}$ \\
\hline & Hasil penelitian koefisien SLF media sosial 0,96. (Edi et al. 2020) \\
\hline \multirow{2}{*}{$\begin{array}{l}\text { Membentuk komunitas untuk } \\
\text { percepatan penyampaian informasi } \\
\text { kepada masyarakat }\end{array}$} & $\begin{array}{l}\text { Interaksi sosial yang erat di antara para pelaku organisasi membantu dalam } \\
\text { mempromosikan transfer pengetahuan (Zahra et al. 2000) }\end{array}$ \\
\hline & Hasil penelitian koefisien SLF pengetahuan 0,95 (Edi et al. 2020) \\
\hline \multicolumn{2}{|l|}{ PENERIMA } \\
\hline \multirow{2}{*}{$\begin{array}{l}\text { Meningkatkan kemampuan masyarakat } \\
\text { dalam: memiliki gadget dan pekat data } \\
\text { murah }\end{array}$} & Hasil penelitian nilai koefisien SLF kemampuan masyarakat 0,99 (Edi, 2020) \\
\hline & $\begin{array}{l}\text { Kemudahan dan kesesuain latar belakang penerimaan suatu produk (Hanny et al. } \\
\text { 2019) }\end{array}$ \\
\hline
\end{tabular}

Tabel 6. Reality, perubahan \& aksi

\begin{tabular}{|c|c|c|c|}
\hline \multicolumn{2}{|c|}{$\begin{array}{c}\text { Tahap } 5 \\
\text { Comparisons with Reality }\end{array}$} & \multicolumn{2}{|c|}{$\begin{array}{c}\text { Tahap } 6 \text { dan } 7 \\
\text { Perubahan yang Mungkin Dilakukan dan } \\
\text { Aksi untuk Perbaikan Situasi }\end{array}$} \\
\hline Model Konseptual & $\begin{array}{l}\text { Kondisi Nyata } \\
\text { di tiga Kecamatan }\end{array}$ & Usulan Perubahan & Aksi untuk Perbaikan Situasi \\
\hline \multicolumn{4}{|l|}{ SUMBER } \\
\hline $\begin{array}{l}\text { Membuat Value Mobile } \\
\text { Money yang sesuai dengan } \\
\text { keinginan dan kebutuhan } \\
\text { masyarakat pedesaan }\end{array}$ & $\begin{array}{l}\text { Value yang dirasakan } \\
\text { masyarakat hanya sebagai } \\
\text { alat pembayaran non tunai } \\
\text { untuk transportasi dan } \\
\text { pembelian makanan }\end{array}$ & $\begin{array}{l}\text { Memberikan Value untuk } \\
\text { transaksi penjualan produk/ } \\
\text { hasil tani dan pembelian } \\
\text { kebutuhan masyarakat } \\
\text { pedesaan }\end{array}$ & $\begin{array}{l}\text { Value dan feature untuk } \\
\text { transaksi pertanian, } \\
\text { peternakan, pengrajin, } \\
\text { transfer, simpan pinjam yang } \\
\text { aman dan mudah }\end{array}$ \\
\hline $\begin{array}{l}\text { Kepedulian provider untuk } \\
\text { menjadikan masyarakat } \\
\text { pedesaan sebagai target } \\
\text { pasar }\end{array}$ & $\begin{array}{l}\text { Masyarakat pedesaan } \\
\text { belum menjadi target pasar } \\
\text { karena kendala teknis dan } \\
\text { volume bisnis }\end{array}$ & $\begin{array}{l}\text { Masyarakat pedesaan } \\
\text { sebagai target market untuk } \\
\text { pengembangan bisnis } \\
\text { provider mobile money }\end{array}$ & $\begin{array}{l}\text { Perluasan merchant mobile } \\
\text { money dengan merangkul } \\
\text { KUD, Toko kelontong, Mini } \\
\text { market, UKM }\end{array}$ \\
\hline $\begin{array}{l}\text { Digitalisasi proses } \\
\text { diseminasi melalui } \\
\text { penerapan ICT untuk } \\
\text { masyarakat di } 3 \text { kecamatan }\end{array}$ & $\begin{array}{l}\text { Proses diseminasi di tiga } \\
\text { kecamatan tersebut masih } \\
\text { dilakukan secara tradisional } \\
\text { melalui penyuluhan tatap } \\
\text { muka }\end{array}$ & $\begin{array}{l}\text { Membentuk Grup WA } \\
\text { kelompok tani, petugas } \\
\text { Pemda, team community, } \\
\text { provider mobile money }\end{array}$ & $\begin{array}{l}\text { Grup WA di kelola oleh } \\
\text { masyarakat dan petugas } \\
\text { Pemda }\end{array}$ \\
\hline $\begin{array}{l}\text { Feature layanan yang } \\
\text { dibutuhkan, mudah } \\
\text { dan sering dipakai oleh } \\
\text { masyarakat pedesaan }\end{array}$ & $\begin{array}{l}\text { Belum ada feature agro } \\
\text { yang berpihak untuk } \\
\text { kebutuhan rutinitas } \\
\text { masyarakat pedesaan }\end{array}$ & $\begin{array}{l}\text { Membuat feature } \\
\text { layanan AGRO yang } \\
\text { mengakomodasi kebutuhan } \\
\text { pokok masyarakat pedesaan }\end{array}$ & $\begin{array}{l}\text { Menambahkan feature AGRO } \\
\text { dengan meningkatkan jumlah } \\
\text { merchant di pedesaan (KUD } \\
\text { dan toko kelontong) }\end{array}$ \\
\hline $\begin{array}{l}\text { Membuat program } \\
\text { sweetener yang menarik } \\
\text { bagi masyarakat pedesaan }\end{array}$ & $\begin{array}{l}\text { Sweetener dirasakan pada } \\
\text { saat pertama kali Gojek dan } \\
\text { Grap masuk di kabupaten } \\
\text { Tasikmalaya }\end{array}$ & $\begin{array}{l}\text { Provider, Pemda dan } \\
\text { merchant bekerjasama } \\
\text { membuat program } \\
\text { "sweetener" yang menarik } \\
\text { bagi masyarakat pedesaan }\end{array}$ & $\begin{array}{l}\text { Program sweetener untuk } \\
\text { pembelian pupuk/bibit di } \\
\text { KUD, pembayaran PBB } \\
\text { dengan mobile money }\end{array}$ \\
\hline
\end{tabular}


Tabel 6. Reality, perubahan \& aksi (lanjutan)

\begin{tabular}{|c|c|c|c|}
\hline \multicolumn{2}{|c|}{$\begin{array}{c}\text { Tahap } 5 \\
\text { Comparisons with Reality }\end{array}$} & \multicolumn{2}{|c|}{$\begin{array}{c}\text { Tahap } 6 \text { dan } 7 \\
\text { Perubahan yang Mungkin Dilakukan dan } \\
\text { Aksi untuk Perbaikan Situasi }\end{array}$} \\
\hline Model Konseptual & $\begin{array}{l}\text { Kondisi Nyata } \\
\text { di tiga Kecamatan }\end{array}$ & Usulan Perubahan & Aksi untuk Perbaikan Situasi \\
\hline \multicolumn{4}{|l|}{ AKTIVITAS } \\
\hline $\begin{array}{l}\text { Peraturan Bank Indonesia } \\
\text { Nomor 20/6/PBI/2018 } \\
\text { tentang Uang Elektronik } \\
\text { perlu disosialisasikan } \\
\text { melalui cabang dan mitra BI }\end{array}$ & $\begin{array}{l}\text { Mayoritas masyarakat } \\
\text { pedesaan tidak mengetahui } \\
\text { dan peduli tentang regulasi } \\
\text { uang elektronik }\end{array}$ & $\begin{array}{l}\text { Penyampaian regulasi dan } \\
\text { jaminan keamanan dalam } \\
\text { melakukan transaksi dengan } \\
\text { mobile money }\end{array}$ & $\begin{array}{l}\text { Kantor cabang BI } \\
\text { mensosialisasi regulasi } \\
\text { melalui perangkat desa, radio } \\
\text { daerah, SMS broadcast dan } \\
\text { Grup WA }\end{array}$ \\
\hline $\begin{array}{l}\text { Pemda membangun } \\
\text { ekosistem digital dengan } \\
\text { penerapan kebijakan } \\
\text { penggunaan mobile money } \\
\text { dalam bertransaksi harian } \\
\text { masyarakat pedesaan }\end{array}$ & $\begin{array}{l}\text { Pembangunan masyarakat } \\
\text { digital belum menjadi } \\
\text { prioritas utama pemerintah } \\
\text { daerah }\end{array}$ & $\begin{array}{l}\text { Kebijakan top down dari } \\
\text { Pemda untuk penggunaan } \\
\text { mobile money untuk } \\
\text { transaksi yang dibawah } \\
\text { kendali Pemda }\end{array}$ & $\begin{array}{l}\text { Penggunaan mobile money } \\
\text { untuk pembayaran : PBB, } \\
\text { transkasi di KUD, tempat } \\
\text { rekreasi, pajak daerah, } \\
\text { distribusi bantuan dana }\end{array}$ \\
\hline $\begin{array}{l}\text { Proses digitalisasi } \\
\text { perlu didukung dengan } \\
\text { penyediaan program } \\
\text { Smartphone \& paket data } \\
\text { yang murah }\end{array}$ & $\begin{array}{l}\text { Smartphone dan paket data } \\
\text { masih dianggap mahal dan } \\
\text { bukan menjadi kebutuhan } \\
\text { utama bagi masyarakat } \\
\text { pedesaan }\end{array}$ & $\begin{array}{l}\text { Melakukan program } \\
\text { bundling untuk pengadaan } \\
\text { smartphone, paket data dan } \\
\text { promo mobile money }\end{array}$ & $\begin{array}{l}\text { Program bundling pengadaan } \\
\text { smartphone dan paket data } \\
\text { murah yang berkolaborasi } \\
\text { antar lembaga }\end{array}$ \\
\hline \multicolumn{4}{|l|}{ MEDIA } \\
\hline $\begin{array}{l}\text { Informasi dalam bentuk } \\
\text { video, sering dan } \\
\text { terdokumentasi akan mudah } \\
\text { dipahami oleh masyarakat }\end{array}$ & $\begin{array}{l}\text { Infromasi disampaikan } \\
\text { melalui penyuluh, dalam } \\
\text { satu waktu dan tidak } \\
\text { terdokumentasi dengan } \\
\text { baik }\end{array}$ & $\begin{array}{l}\text { Informasi mobile money } \\
\text { harus dibuat dalam bentuk } \\
\text { video yang menarik, singkat } \\
\text { dan mudah dipahami }\end{array}$ & $\begin{array}{l}\text { Informasi dalam bentuk video } \\
\text { di sebarkan ke komunitas } \\
\text { melalui media sosial secara } \\
\text { kontinyu }\end{array}$ \\
\hline $\begin{array}{l}\text { Penyampaian informasi } \\
\text { melalui media sosial }\end{array}$ & $\begin{array}{l}\text { Penyampaian melalui tatap } \\
\text { muka dan belum terbiasa } \\
\text { melalui media sosial }\end{array}$ & $\begin{array}{l}\text { Menggalakan komunikasi } \\
\text { dan koordinasi melalui } \\
\text { media sosial secara } \\
\text { bertanggung jawab }\end{array}$ & $\begin{array}{l}\text { Pemda berinisiatif } \\
\text { membentuk grup WA (Grup } \\
\text { Desa, Grup RW, Grup RT, } \\
\text { Komunitas) }\end{array}$ \\
\hline $\begin{array}{l}\text { Membentuk komunitas } \\
\text { untuk percepatan } \\
\text { penyampaian informasi } \\
\text { dan pemahaman kepada } \\
\text { masyarakat }\end{array}$ & $\begin{array}{l}\text { Kelompok petani dalam } \\
\text { lingkup terbatas sudah } \\
\text { terbentuk dengan media } \\
\text { komunikasi tatap muka }\end{array}$ & $\begin{array}{l}\text { Pembentukan komuniitas } \\
\text { mobile money dengan } \\
\text { didukung media komuniaksi } \\
\text { sosial }\end{array}$ & $\begin{array}{l}\text { Provider mobile money } \\
\text { me maintain komunitas } \\
\text { melalui update informasi dan } \\
\text { program yang menarik }\end{array}$ \\
\hline \multicolumn{4}{|l|}{ PENERIMA } \\
\hline $\begin{array}{l}\text { Meningkatkan kemampuan } \\
\text { masyarakat dalam memiliki } \\
\text { gadget, paket data, } \\
\text { Penggunaan medsos }\end{array}$ & $\begin{array}{l}\text { Kemampuan untuk } \\
\text { membeli smartphone dan } \\
\text { berlangganan paket data } \\
\text { masih terbatas dikalangan } \\
\text { menengah keatas dan anak } \\
\text { muda }\end{array}$ & $\begin{array}{l}\text { Memberikan kemudahan } \\
\text { dan keringan untuk memliki } \\
\text { smartphone dan paket data } \\
\text { bagi masyarakat desa }\end{array}$ & $\begin{array}{l}\text { Program cicilan handphone } \\
\text { dan paket data dengan } \\
\text { persyaratan yang mudah dan } \\
\text { murah bagi masyarakat }\end{array}$ \\
\hline
\end{tabular}




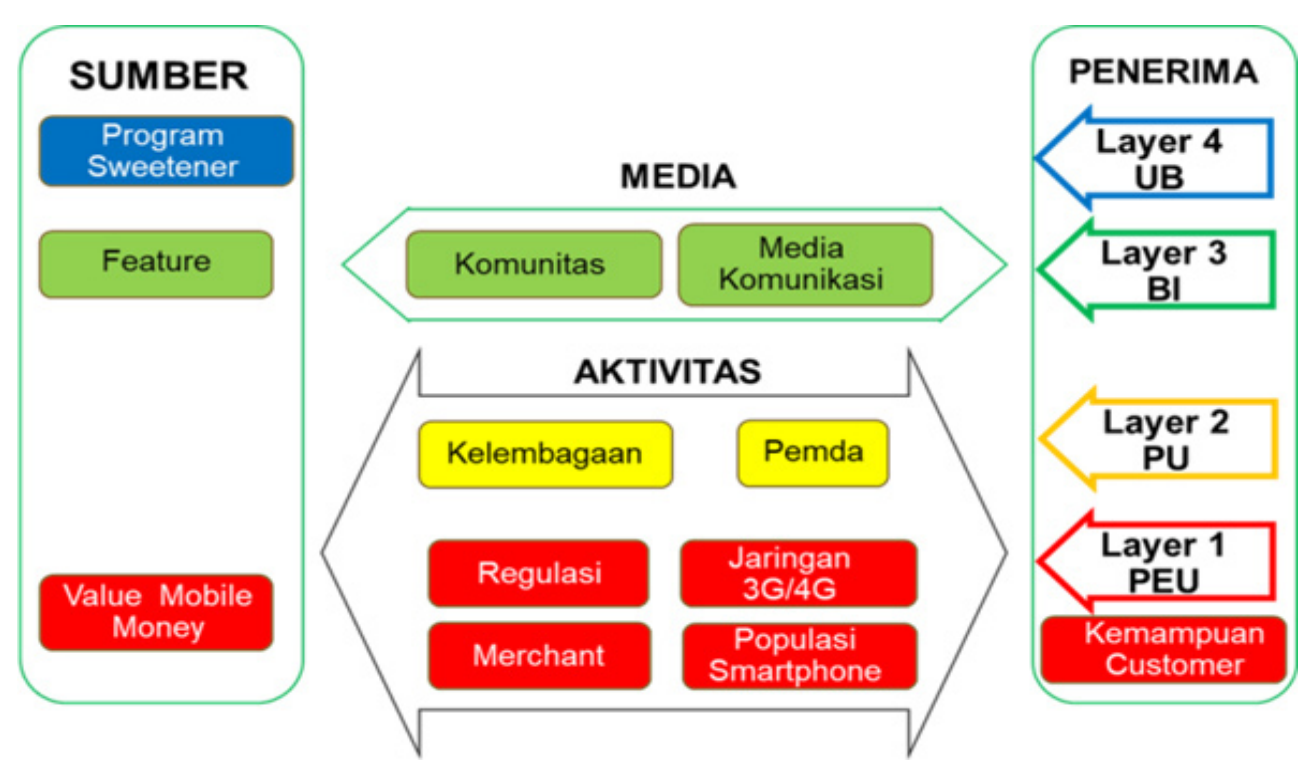

Gambar 3. Model diseminasi 4 layer penerapan mobile money

Layer 2: membangun persepsi manfaat yang dirasakan oleh masyarakat pedesaan dapat dilakukan dengan cara; a) Pemda berinisiatif membangun ekosistem ekonomi digital melalui penerapan mobile money; b) Kebijakan implementasi mobile money untuk pembayaran: PBB, transaksi di KUD, distribusi bantuan dana sosial; c) Provider mobile money mengelola group komunitas dan menyampaikan informasi lewat grup media sosial; d) Pemda berinisiatif membentuk group "whatsapp" (Grup Desa, Grup RW, Grup RT, komunitas petani, komunitas peternak dan komunitas pengrajin). Hipotesis 2 (H2) terbukti bahwa Persepsi manfaat merupakan kritikal faktor kedua yang harus dipenuhi. Mehta et al. (2019) dalam penelitiannya juga mengatakan bahwa peran pemerintah dan provider mobile banking untuk memprioritaskan penerapan mobile banking di pedesaan akan mempercepat terwujudnya penerepan mobile banking di pedesaan.

Layer 3: Membangun Behavioural Intention: a) Menyediakan feature layanan agro dengan feature, penjualan hasil tani, pembelian pupuk dan bibit, distribusi dan pendananaan dengan meningkatkan jumlah merchant di pedesaan (KUD dan toko kelontong); b) Membangun komunitas ekonomi digital pedesaan dengan menggunakan media sosial sebagai sarana komunikas; c) Update informasi mobile money dalam bentuk video disebarkan melalui komunitas lewat media sosial ("whatsapp" grup) secara rutin. Hipotesis 3 (H3) terbukti bahwa membangun behavioural intention merupakan kritikal faktor ketiga yang harus dipenuhi. Hal ini sejalan dengan hasil penelitian yang dilakukan (Nonaka, 1996; Szulanski, 1996) yang menyimpukan bahwa menciptakan hubungan yang baik antara sumber atau penyelenggara mobile money dan penerima (masyarakat pedesaan) akan mempercepat proses transfer pengetahuan.

Layer 4: Membangun Usage Behaviour: Program sweetener yang menarik untuk pembelian pupuk, bibit di KUD, pembayaran PBB, serta penjualan hasil panen dengan mobile money. Hipotesis 4 (H4) terbukti bahwa membangun usage behaviour merupakan kritikal faktor keempat yang harus dipenuhi.

\section{Implikasi Manajerial}

Proses diseminasi penerapan mobile money di masyarakat pedesaan perlu di dukung dengan beberapa kebijakan yang dikeluarkan oleh lembagalembaga terkait yang berperan penting dalam proses implementasi. Beberapa kebijakan yang perlu dipersiapkan antara lain:

1. Kebijakan provider telekomunikasi: a) mengupgrade dan meningkatkan jangkauan jaringan 3G/4G ke area pedesaan; b) mengeluarkan paket bundling (gadget dan paket data dan suara) untuk segmentasi masyarakat pedesaan.

2. Kebijakan Provider Mobile Money: a) pengembangan target market ke masyarakat pedesaan; b) menyediakan feature layanan yang sesuai dengan kebutuhan masyarakat pedesaan; c) membuat program sweetener yang menarik bagi masyarakat desa dan kelompok tani; d) kebijakan kemitraan yang menarik untuk para merchant dan 
UKM.

3. Kebijakan pemerintah daerah: a) mengeluarkan kebijakan bertransaksi dengan mobile money untuk distribusibantuansosial, pembayaran transaksiKUD, pembayaran $\mathrm{PBB}$, pembayaran di puskesmas dan transaksi lainnya yang dibawah otoritas Pemda; b) pemberdayaan UMKM sektor pertanian dan industri dengan membentuk komunitas agen perubahan di desa-desa yang beranggotakan anak muda sebagai interface dalam menerima perkembangan teknologi; c) bekerjasama dengan provider mobile money dan telekomunikasi untuk menyiapkan infrastruktur dengan memberikan kemudahan dalam perijinan.

4. Kebijakan Perbankan: a) kebijakan penyediaan mesin ATM; b) mengeluarkan kebijakan cicilan untuk pembelian gawai.

\section{KESIMPULAN DAN SARAN}

\section{Kesimpulan}

Penerapan mobile money perlu dikembangkan di masyarakat pedesaan, untuk meningkatkan kesejahteraan masyarakat. Penerapan mobile money ini merupakan langkah yang strategis untuk meningkatkan literasi keuangan masyarakat pedesaan sehingga dapat mendukung pengembangan agribisnis di Indonesia. Pendekatan Soft System Methodology mampu menguraikan permasalahan dengan baik dan menemukan model konseptual yang tepat.

Model diseminasi untuk penerapan mobile money di masyarakat pedesaan Kabupaten Tasikmalaya terbagi menjadi empat layer, yaitu 1) membangun persepsi kemudahaan dengan memberikan nilai tambah yang lebih baik, pemahaman regulasi, perluasan merchant, ketersediaan jaringan 3G/4G, kemudahan mendapatkan gawai dan pengenalan dan update informasi dalam bentuk video melalui media sosial; 2) membangun ekosistem ekonomi digital, kebijakan implementasi mobile money, membangun komunitas; 3) menyediakan feature layanan AGRO, membangun komunitas dengan memanfaatkan media komunikasi; 4) membuat program sweeteener yang menarik untuk pembelian pupuk, bibit di KUD, serta pembayaran PBB dengan mobile money.

\section{Saran}

Mengacu kepada keberhasilan implementasi non tunai untuk pembayaran di jalan tol dan KRL dimana titik kritis keberhasilannya adalah kesiapan sarana infrastruktur. Selanjutnya, peran pemerintah dan lembaga terkait dalam berkolaborasi membangun infrastruktur dan kebijakan top down penggunaan e money. Model diseminasi mobile money untuk masyarakat pedesaan dengan hasil akhir masyarakat menjadi terbiasa menggunakan mobile money perlu dilakukan secara system. Menyiapkan sarana dan prasara yang dipetakan dalam model 4 layer perlu kolaborasi antara lembaga terkait untuk menciptakan ekosistem mobile money di pedesaan. Kebijakan top down Pemda akan sangat berperan dalam keberhasilan diseminasi mobile money. Penelitian yang dilakukan masih banyak kekurangannya sehingga perlu dilakukan penelitian lain dengan sudut pandang dan lokasi yang berbeda sehingga lebih memperkaya khasanah keilmuan model diseminasi.

\section{DAFTAR PUSTAKA}

[BI] Bank Indonesia. 2020. Transaksi Uang Elektronik. https://www.bi.go.id/id/default.aspx.

Barakabitze AA, Kitindi EJ, Sanga C, Ayubu S, Masamaki J, Kibirige G. 2015. New Technologies for disseminating and communicating agriculture knowledge and information: challenges for agricultural research institutes in Tanzania. Electronic Journal of Information Systems in Developing Countries (EJISDC). 70(2):122. https://doi.org/10.1002/j.1681-4835.2015. tb00502.x.

[BPS] Badan Pusat Statistik Tasikmlaya. https:// tasikmalayakab.bps.go.id/

Hafiar H, Setianti Y, Subekti P. 2019. Dissemination of banking services information and people with visual impairment. Library Philosophy and Practice. 3568.

Jamal E, Mardiharini M, Sarwani M. 2008. Proses diseminasi pengelolaan tanaman dan sumberdaya terpadu padi: suatu pembelajaran dan perspektif ke depan. Analisis Kebijakan Pertanian 6 (3): $272-285$.

KukrejaA, ChakrabartiB. 2013.Agricultural knowledge management and dissemination: initiatives by information and communication technology. 
Journal of Global Communication. 6 (1): 51-58. https://doi.org/10.5958/j.0976-2442.6.1.006.

Mehta A, Chakrabarti D, Srivastava R, Mehta R. 2019. Mobile Banking - An Answer to Financial Inclusion in Hilly Rural India. International Journal of Recent Technology and Engineering (IJRTE) 8(4): 1730-1738. https://doi. org/10.35940/ijrte.C5822.118419.

Munyegera GK, Matsumoto T. 2015. ICT for financial access: mobile money and the financial behavior of rural farm households in Uganda. Review of Development Economics 22(1):45-66. https:// doi.org/10.1111/rode.12327.

Nonaka I, Takeuchi H, Umemoto K. 1996. A theory of organizational knowledge creation. International Journal of Technology Management 11(7): 833845.

Ramdhani D. 2019. Ini alasan Kabupaten Tasikmalaya dapat bantuan tertinggi di Jawa Barat. https://regional.kompas.com/ $\mathrm{read} / 2019 / 12 / 10 / 15121301 /$ ini-alasankabupaten-tasikmalaya-dapat-bantuankeuangan-tertinggi-di-jabar [10 Des 2019].

Sukmadirana E, Seminar KB, Firdaus M, Arkeman Y. 2020. Determining components that are strongly correlated to rural community interest and willing in using And utilizing mobile money in Tasikmalaya District. European Journal of Business and Management 12 (30): 63-73.
Szulanski G. 1996. Exploring internal stickiness: impediments to the transfer of best practice within the firm. Strategic Management Journal 20(S2):27-43. https://doi.org/10.1002/ smj. 4250171105.

Widi A, Ermatita. 2016. Pengembangan Knowledge Management System dengan model SECI dan pendekatan Soft System Methodology.

Prihandoyo WB. 2014. Efektivitas Diseminasi Informasi Pertanian Melalui Media telepon Genggam Pada Petani Sayuran di Kecamatan Pacet Kabupaten Cianjur

Yongjian L, Shi XL, Wang W. 2015. Influencing factors of knowledge dissemination in rural areas in China. Nankai Business Review International 6(2):128-155. https://doi.org/10.1108/NBRI-052014-0026.

Simonin BL. 1999. Ambiguity and the process of knowledge transfer in strategic alliances. Strategic Management Journal 20(7): 595-623.

Zahra SA, Ireland RD, Hitt MA. 2000. International expansion by new venture firms: international diversity, mode of market entry, technological learning, and performance. Academy of Management Journal 43(5): 925-950. https:// doi.org/10.5465/1556420.

Zander U, Kogut B. 1995. Knowledge and the speed of the transfer and imitation of organizational capabilities: an empirical test. Organization Science 6(1): 76-92. https://doi.org/10.1287/ orsc.6.1.76. 